\title{
PERILAKU SEHAT PENDERITA KUSTA DENGAN KEPATUHAN KONSUMSI $M D T$ DI PUSKESMAS LIMO KOTA DEPOK JAWA BARAT
}

\author{
Tatiana Siregar ${ }^{1}$, Diah Ratnawati ${ }^{2)}$ \\ ${ }^{1)}$ Prodi D III Keperawatn Fakultas Ilmu Kesehatan - UPN Veteran Jakarta \\ ${ }^{2)}$ Prodi Ners, Fakultas Ilmu Kesehatan - UPN Veteran Jakarta \\ E-mail: tatian siregar@upnvj.ac.id
}

\begin{abstract}
Leprosy is a disease caused by the bacterium Mycobacterium leprae, will attack the skin and peripheral nerves, and is transmitted through the upper respiratory tract. Management of leprosy requires patient patience in treatment, because it takes a long time. Patient compliance in the treatment process determines the success of treatment. Healtby behavior in the management of leprosy treatment requires discipline in taking leprosy medication. Poor treatment management can have permanent damage to the limbs of the patient, which is the occurrence of disability. The purpose of this study was to determine the main factor dimensions of healthy behavior that affect leprosy compliance in consuming Multi Drug Therafi (MDT) of leprosy. The research design used cross sectional descriptive, the sampling technique used was a total sampling of 15 people. The research instrument used a questionnaire containing statements of compliance and healthy behavior consisting of dimensions of knowledge, attitudes and psychomotor, and analyzed using multiple linear regression. The results obtained that the factors of knowledge, attitudes, and psychomotor have a positive and significant effect on patient compliance consuming MDT ( $p$ value $<0.005$ ), the dimension of knowledge is the main factor influencing compliance with a p value of 0.001 . Overall, the determinant coefficient of knowledge, attitudes, and behavior towards adherence of lepers has a very strong relationship $(R=0.809)$. So the researchers advise lepers to behave healthily in carrying out drug compliance to prevent disability and the need for supervisors to take medication for lepers.
\end{abstract}

Keywords: Mycobacterium leprae; Leprosy Patients; linear regression.

\begin{abstract}
ABSTRAK
Penyakit kusta merupakan penyakit yang disebabkan oleh bakteri Mycobacterium leprae, akan menyerang kulit dan saraf tepi, serta ditularkan melalui saluran pernafasan atas. Penatalaksanaan penyakit kusta perlu kesabaran penderita dalam pengobatan, karena membutuhkan waktu yang lama. Kepatuhan penderita dalam proses pengobatan menentukan keberhasilan pengobatan. Perilaku sehat dalam penatalaksanaan pengobatan kusta membutuhkan kepatuhan disipilin dalam mengonsumsi obat kusta. Penatalaksanaan pengobatan yang buruk dapat berdampak kerusakan permanen pada anggota tubuh penderita yaitu terjadinya kecacatan tubuh. Tujuan penelitian untuk mengetahui faktor utama dimensi dari perilaku sehat yang mempengaruhi kepatuhan penderita kusta dalam mengonsumsi Multi Drug Therafi (MDT) penyakit kusta. Desain penelitian menggunakan deskritif cross sectional,

Cara mengutip: Siregar, Tatiana \& Ratnawati, Diah. (2019). Perilaku Sehat Penderita Kusta dengan Kepatuhan Konsumsi MDT di Puskesmas Limo Kota Depok Jawa Barat. Care:Jurnal Ilmiah Ilmu Kesehatan, 7(3), 127-137


teknik sampel yang digunakan secara total sampling sebanyak 15 orang. Instrumen penelitian menggunakan kuesioner yang berisi pernyataan kepatuhan serta perilaku sehat yang terdiri dari dimensi pengetahuan, sikap dan psikomotor, dan dianalisa dengan menggunakan regresi linier berganda. Hasil didapat bahwa faktor pengetahuan, sikap, dan psikomotor memiliki pengaruh positif dan signifikan dengan kepatuhan penderita mengonsumsi MDT ( $p$ value $<$ $0,005)$, dimensi pengetahuan merupakan faktor utama yang mempengaruhi kepatuhan dengan nilai $p$ value 0,001 . Secara keseluruahan koefisien determinan pengetahuan, sikap, dan perilaku terhadap kepatuhan penderita kusta mempunyai hubungan yang sangat kuat $(\mathrm{R}=0,809)$. Maka peneliti menyarankan penderita kusta untuk berperilaku sehat dalam menjalankan kepatuhan mengosumsi obat untuk mencegah kecacatan dan perlu adanya pengawas minum obat bagi penderita kusta.

Kata Kunci : Mycobacterium leprae; Penderita Kusta; Regresi linier.

\section{PENDAHULUAN}

Profil Kesehatan RI melaporkan terdapat 17.202 kasus baru kusta dengan 84,5\% kasus di antaranya merupakan tipe Multi Basiler (MB), dan Jawa Barat merupakan urutan kedua yang mempunyai kasus kusta baru terbanyak serta termasuk provinsi beban kusta bigh burden yaitu sebanyak 2026 orang atau New Case Detection Rate (NCDR) $34 \%$, jenis kusta MB sebanyak 2.223 orang dan PB 125 orang dari jumlah penduduk Jawa Barat sebanyak 46.709.569 jiwa (Kemenkes RI, 2015) .

Sedangkan laporan Dinkes Kota Depok tahun 2016 ditemukan ada 40 penderita kusta Baru dengan wilayah Puskesmas Limo sebanyak 16 penderita, Puskesmas Cipayung terdapat 14 penderita, dan Puskesmas Bojongsari sebanyak 10 penderita (Depok Pos, 2017).

Kelurahan Limo merupakan bagian dari wilayah Kota Depok, yang didapatkn 16 penderita baru, dan hasil penelitian Siregar \& Ratnawati (2018) dari 9 penderita kusta di
Kelurahan Limo hidupnya berada di garis kemiskinan, membuat penderita malas untuk kontrol secara rutin datang berobat ke Puskesmas, sehingga penderita menjalankan pengobatan dan perawatan belum optimal, terutama dalam kepatuhan mengonsusmi obat secara rutin. Laporan Puskesmas tercatat dari 9 orang yang terdata di Puskesmas, masih ada 3 orang yang tidak disiplin dalam berobat (Puskesmas Limo, 2018)

Pengobatan kusta memerlukan penanganan yang cepat dan berkelanjutan serta memerlukan kedisiplinan dalam pengobatan. Pengobatan kusta membutuhkan waktu yang lama. Kusta tipe PB membutuhkan waktu $6-9$ bulan, sedangkan tipe MB membutuhkan waktu 12 - 18 bulan. Pengobatan penderita kusta bertujuan untuk memutuskan mata rantai penularan, menyembuhkan penyakit penderita, mencegah terjadinya cacat atau mencegah bertambahnya cacat yang sudah 
ada dalam pengobatan (Kemenkes RI, pelaksanaan program pengobatan kusta 2014).

yang dicanagkan pemerintah dalam

Pengobatan yang lama ini memiliki risiko mencegah kecacatan sangat penting tinggi dalam ketidakpatuhan berobat dan minum obat bagi penderita (Kemenkes RI, 2014). Seperti riset Wiyarni, (2013) menyimpulkan sebanyak 48 orang $(62,3 \%)$ penderita kusta tidak patuh dalam minum obat. Ketidakpatuhan seseorang dalam pengobatan juga sebagai pendukung morbiditas, mortalitas dan biaya perawatan kesehatan yang cukup besar (Gurumurthy, 2018)

Banyak faktor yang mempengaruhi kepatuhan penderita kusta dalam mengkonsumsi MDT. Beberapa penelitian mengungkapkan kepatuhan seseorang dalam mengonsumsi obat karena lupa, tidak suka obat tersebut, efek samping dari obat yang tidak disukai, kondisi merasa lebih baik dan biaya (Morisky, 2015). Faktor-faktor tersebut sangat ditentukan oleh perilaku sehat dari penderita dalam kepatuhan mengonsumsi obat. Ketaatan minum obat adalah salah satu yang paling menarik dan kompleks dari perilaku pasien. Ketidakpatuhan pada rejimen obat dapat menghasilkan hasil yang negatif, dan dapat ditambah pada populasi dengan penyakit kronis karena durasi waktu yang panjang dalam pengobatan semua ini ditentukan dari perilaku sehat penderita (Cognizant, 2014).

Maka berdasarkan latar belakang yang ada terkait dengan partisipasi penderita dalam

\section{METODE PENELITIAN}

Penelitian ini menggunakan desain penelitian deskritif cross sectional, dan analisa data menggunakan regresi berganda. Sampel yang digunakan total sampling hanya 15 orang penderita kusta yang aktif di Puskesmas Limo Depok.

Pengambilan data menggunakan kuesioner yang berisi peryataan dari dimensi variabel perilaku sehat konsep (Notoadmodjo, 2007): 10 pernyataan pengetahuan, 10 pernyataan sikap, dan 10 pernytaan psikomotor; serta varibel kepatuhan diambil dari (Bruner and Sudarth, 2014) dengan 12 pernyataan, bentuk jawaban kuesioner menggunakan skala likert. Hasil uji reliabilitas validitas dilakukan pada penderita yang berobat kontrol di Puskemas sebanyak 20 reponden dengan hasil sikap (reliabilitas 0,912 dan validitas 0,584 0,870 ), pengetahuan (reliabilitas 0,922 dan 
validitas $0,410-0,533)$, psikomotor (reliabilitas 0,946 dan validitas 0,525 0,976), serta kepatuhan (reliabilitas 0,940 dan validitas $0,532-0,931)$.

Hasil analisa data untuk menjawab hipotesa menggunakan Regresi Linier Berganda, namun untuk memenuhi syarat penggunanaan metode analisa data ini dilakukan ujia asumsi penggunaan model linier berganda terlebih dahulu berupa uji asumsi eksistensi, asumsi idependensi, uji homoscedasiticiy, asumsi normalitas dan multikolinearitas (Hastono, S.P., 2018 dan Sunyoto, 2011).

\section{HASIL}

Tabel 1 berikut menjelaskan karakteristik responden penderita kusta, bahwa penderita kusta usia termuda ada 1 dikatagroikkan dibawah usia 17 tahun dengan data asli usia 4 tahun, sedangkan usia $>17$ ada 14 orang $(93,33 \%)$ dan dengan usia tertua dari pendataan 61 tahun satu orang. Jenis kelamin terbanyak adalah laki-laki sebanyak 9 orang (60\%). Pendididkan penderita terbanyak SMA sebanyak 8 orang $(53,33 \%)$, Jenis Kusta terbanyak adalah tipe Multi Basiler sebanyak 13 orang (86,7\%), lama menderita kusta lebih dari 12 bulan juga sebanyak 13 orang $(86,7 \%)$.

Melihat data karakteristik ini juga telah disesuaikan dengan data dari Puskesmas dan saat kunjungan rumah untuk validasi, terutama kehidupan sehari-hari penderita semua berada pada kondisi miskin.

Tabel 1. Distribusi Frekuensi Karakteristik Reponden Penderita Kusta Di Kelurahan Limo Depok.

\begin{tabular}{|c|c|c|}
\hline Variabel & f & $(\%)$ \\
\hline \multicolumn{3}{|l|}{ Usia: } \\
\hline Anak ( $\leq 17$ tahun $)$ & 1 & 6,7 \\
\hline Pemuda ( $>17$ tahun) & 14 & 93,3 \\
\hline \multicolumn{3}{|l|}{ Jenis Kelamin: } \\
\hline Laki-Laki & 9 & 60 \\
\hline Perempuan & 6 & 40 \\
\hline \multicolumn{3}{|l|}{ Pendidikan: } \\
\hline Pra Sekolah & 1 & 6,7 \\
\hline Dasar & 2 & 13,3 \\
\hline Menengah Pertama & 4 & 26,67 \\
\hline Menengah Atas & 8 & 53,33 \\
\hline \multicolumn{3}{|l|}{ Pekerjaan: } \\
\hline IRT & 5 & 33,33 \\
\hline Karyawan Swasta & 1 & 6,7 \\
\hline Wiraswasta & 4 & 26,67 \\
\hline Buruh & 4 & 26,67 \\
\hline Pelajar & 1 & 6,7 \\
\hline \multicolumn{3}{|l|}{ Jenis Kusta } \\
\hline Pauli Basiler & 2 & 13,3 \\
\hline Multi Basiler & 13 & 86,7 \\
\hline \multicolumn{3}{|c|}{ Lama Menderita Kusta } \\
\hline$>12$ bulan & 2 & 13,3 \\
\hline & 13 & 86,7 \\
\hline
\end{tabular}

\section{Hasil Uji Asumsi Linier Berganda}

Uji Asumsi terpenuhi semua karena, pada 1) Asumsi eksistensi, dimana nilai mean berada di analisa statistik residual 0,000 dan standar deviasi 0,805, 2) Asumsi independensi dengan nilai Durbin Watson 1,813 yang berarti direntang -2 sampai dengan +2; 3) Asumsi Homscedascity, didapat titik tebaran tidak berpola tertentu dan mentebar merata di sekitar garis tiik nol maka dapat disebut, varian homogeny 
pada setiap nilai $\mathrm{x}$; 4) Asumsi Liniearitas, dari hasil uji ANOVA p value $0,000<$ 0,005, berarti model berbentuk linier; 5) Asumsi Normalitas, dimana Plot residual data menyebar di sekitar garis diagonal dan mengikuti arah garis , maka model memenuhi asumsi model regresi., 6) Diagnostik Multikolinearitas, dilihat pada nilai VIF $<10$ (Pengetahuan VIF 1,180, Sikap VIF 1,171, dan Psikomotor VIF 1,031).

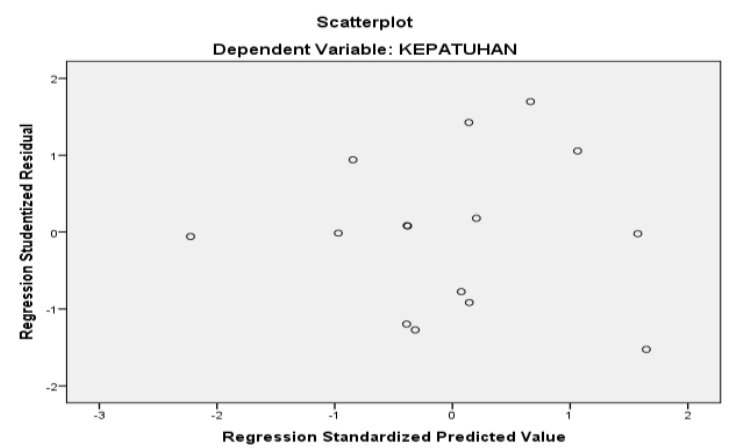

Gambar 1. Asumsi Hemoscedascity
Tabel 2. Distribusi Pengetahuan, Sikap, Psikomotor, dan Kepatuhan Penderita Kusta di Kelurahan Limo Depok

\begin{tabular}{lcccc}
\hline Variabel & Mean & SD & \multicolumn{2}{c}{ Min - } \\
\hline Pengetahuan & 38 & 1,464 & 34 & 40 \\
Sikap & 36,87 & 1,246 & 35 & 39 \\
Psikomotor & 35,87 & 0,834 & 35 & 38 \\
Kepatuhan & 45,53 & 1,767 & 42 & 48 \\
\hline
\end{tabular}

Distribusi sub variabel pengetahuan ratarata pada nilai 38 , sub variabel sikap pada nilai 36,87, dan sub varibel psikomotor 35,87; sedangkan variabel kepatuhan ratarata pada nilai 45,53 .

Tabel 3. Koefisien Determinasi Kepatuhan Penderita Kusta di Limo Depok

\begin{tabular}{cccc}
\hline $\mathbf{R}$ & $\mathbf{R}$ Square & Adjusted $\mathbf{R}$ Square & Standar Eror dari Estimasi \\
\hline & & \\
& 0,793 & 0,736 & 0,908 \\
\hline
\end{tabular}

Tabel 3 dijelaskan nilai $R$ square $\left(R^{2}\right)$ sebesar 0,890, hal ini berarti $89,0 \%$ dari variabel kepatuhan penderita kusta dijelaskan oleh variabel pengetahuan, sikap, dan psikomotor, sedangkan sisanya $11 \%$ dijelaskan oleh sebab lain, koefisien korelasinya katagorik sangat kuat.

Hasil peritungan pada tabel 4 diperoleh persamaan regresi dari hubungan pengetahuan, sikap, dan psikomotor dengan kepatuhan mengkonsumsi MDT adalah:

$$
\begin{aligned}
Y= & a_{0}+b_{1} X_{1}+b_{2} X_{2}+b_{3} X_{3} \\
= & \underset{\quad-41,728}{ } \underset{0,818 X_{3}}{0,724 X_{1}+0,825 X_{2}+}
\end{aligned}
$$

Konstanta sebesar -41,728 menyatkan bahwa jika tidak ada pengetahuan, sikap, dan psikomotor maka kepatuhan adalah - 
41,728. Koefisien regresi $\mathrm{X}_{1}$ sebesar 0,724 menyatakan bahwa setiap penambahan 1 nilai pengetahuan akan meningkatkan kepatuhan penderita kusta sebesar 0,724. Koefisien regresi $\mathrm{X}_{2}$ sebesar 0,825 menyatakan bahwa setiap penambahan 1 nilai sikap akan menambah kepatuhan penderita kusta sebesar 0,825. Sedangkan koefisien regresi $\mathrm{X}_{3}$ sebesar 0,818 menyatakan bahwa setiap penambahan 1 nilai psikomotor akan meningkatkan kepatuhan penderita kusta mengkonsumsi MDT penyakit kusta sebesar 0,818 .

Hasil uji t, pengetahuan berpengaruh positif dan signifikan terhadap kepatuhan dengan nilai $\mathrm{t}$ hitung 4,300 dan probabilitasnya 0,001; sikap berpengaruh positif dan signifikan terhadap kepatuhan dengan nilai t hitung 3,915 dan probabilitanya 0,002; psikomotor berpengaruh positif terhadap kepatuhan dengan nilai t hitung 2.589 dan probabilitasnya 0,003. Ketiga koefisien regresi signifikan terhadap kepatuhan

Pada tabel 4 juga dijelaskan secara parsial pengetahuan $(\phi$ value $=0,001)$, sikap ( $p$ value $=0,002)$, dan psikomotor ( $p$ value 0,025$)$ berhubungan dengan kepatuhan. Faktor penentu utama dalam kepatuhan secara berturut-turut dari pengetahuan, sikap, dan psikomotor. Dari uji Anova atau F di dapat F hitung 14,204 dengan tingkat signifikan 0,000, yaitu lebih kecil dari 0,05, maka model regresi bisa dipakai untuk memprediksi kepatuhan.

Tabel 4. Hasil Koefisien Regresi Pengetahuan, Sikap, Psikomotor Dengan Kepatuhan Mengkonsusmi MDT Penyakit Kusta Di Puskesmas Limo Depok

\begin{tabular}{|c|c|c|c|c|c|}
\hline \multirow{3}{*}{ Model } & \multirow{2}{*}{\multicolumn{2}{|c|}{ Unstandarized Coefficient }} & Standard & \multirow{3}{*}{$\mathrm{t}$} & \multirow{3}{*}{ Sig } \\
\hline & & & Coefficients & & \\
\hline & $\frac{\mathrm{B}}{11700}$ & Standar Eror & Beta & & \\
\hline Konstanta & $-41,728$ & 16,130 & & $-2,587$ & 0,025 \\
\hline Pengetahuan & 0,724 & 0,168 & 0,599 & 4,300 & 0,001 \\
\hline Sikap & 0,825 & 0,211 & 0,582 & 3,915 & 0,002 \\
\hline Psikomotor & 0,818 & 0,316 & 0,386 & 2,589 & 0.025 \\
\hline
\end{tabular}

PEMBAHASAN.

Berdasarkan data kareakteristirk repsonden pada Tabel 1, didapat data penderita kusta terbanyak adalah jenis MB (Multi Basiler) sebanyak 13 orang $(86,7 \%)$. Penderita kusta dengan jenis MB membutuhkan pengobatan selama 12 bulan, secara tidak langsung sangat membutuhkan kepatuhan penderita dalam pengobatan, karena pengobatan yang tidak tuntas mengakibatkan penderita harus memulai lagi dari tahap awal (WHO, 2014).

Kusta tipe MB lebih berisiko untuk mengalami reaksi kusta (kecacatan) dan 50\% penderita kusta mengalami reaksi kusta pada tahun per-tama setelah didiagnosis 
kusta, reaksi kusta akan me-ningkat pada pasien dengan penyakit kusta lama atau pengobatan kusta yang lama (Nadhiroh, Dharmawan, \& Murti, 2016).

Dari survey langsung ke rumah penderita dan pegamatan bahwa kehidupan penderitan termasuk dalam katagorik miskin, rumah sangat sederhana dan kondisi lingkungan sangat lembab, berisiko penyakit kusta penderita terbanyak dalam katgorik MB. Kondis hidup miskin ditambah adanya penyakit kusta yang didierita menambah stigma dari masyarakat. (Kaehler, Adhikar, Raut, \& Marahatta, 2015). Stigma yang didapat penderita mempengaruhi penderita untuk datang ke pelayanan kesehatan sehingga mempengaruhi juga penderita dalam kepatuhan berobat. stigma sosial dan self-stigma dapat menjadi faktor yang berkontribusi besar untuk mencari pengobatan yang teratur (Irawati, Dwi, Puspitasari, \& Linuwih, 2018) dan berdasarkan riset Oliveira et al (2011) bahwa pendapatan keluarga yang rendah juga mempengaruhi kepatuhan penderita dalam kepatuhan pengobatan

Data karakteristik pada Tabel 1, tingkat pendidikan penderita terbanyak 8 orang SMA $(53,33 \%)$ selebihnya SMP.Riset Siregar \& Ratnawati (2018) dari 9 penderita kusta, empat orang berpendidikan SMP, dan sisanya SD dan SMA, bahwa pasien dan keluarga menyatakan tidak memahami etiologi, pengobatan dan perawatan pada penyakit kusta. Kondisi ini kaitannya dengan pendidikan penderita. Tingkat pendidikan seseorang mempengaruhi wawasan sesorang dalam memahami penyakit atau pengobatannya (Seshadri, et.al, 2014).

Wawasana seseorang dalam memahami sesuatu dalam pengetahuan pengobatan dan perawatan penyakitnya menentukan keberhasilan dalam penyembuhan penyakitnya. Pengetahuan sangat menentukan terlambatnya diagnosa penyakit sehingga tingginya frekuensi diagonsa kusta yang tertunda, ketidaksadaran akan diagnosis, serta kepatuhan dalam pengobatan, waktu yang panjang anatar terpapar gejala dengan waktu diagnosis mencerminkan ketidaktahuan penderita dan ketidak pedulian gejala penyakit kusta (Atre SR., Rangan, 2011). Hampir separuh responden kusta (49,7\%) dari 245 responden tidak mengetahui keparahan gejala seperti bercak merah, bengkak kecil, sensasi kesemutan dirasakan di luka, percaya bahwa gejala akan hilang (Singh, Sinha, \& Jaswal, 2013)

Pengetahuan penderita kusta perlu diberikan karena berkaitan dengan pengobatan khususnya dalam kepatuhan mengonsumsi obat. Hasil riset Rustam (2014) bahwa ada hubungan antara pengetahuan dengan kepatuhan minum obat, pengetahuan mempengaruhi kepatuhan seseorang dalam mengonsumi 
obat, dikarenaka pada risetnya mayoritas penderita kurang mendapat informasi dan edkuasi dari petugas kesehatan tentang penyakit kusta dan tata cara pengobatannya. Hal ini juga didukung dari riset Selum \& Wahyuni (2012) ada pengaruh antara pengetahuan dengan kepatuhan berobat karena semakin banyak informasi yang diperoleh penderita tentang kusta, maka pengetahuan penderita tentang kusta khususnya pentingnya pengobatan untuk kesembuhan kusta akan baik, sehingga penderita dapat termotivasi untuk berobat secara teratur. Terbukti dari riset Brown et al (2016) bahwa 50\% penderita yang mengingat apa yang dibahas saat bertemu dengan dokter mengenai penyakitnya, hal ini akan mempengaruhi kepatuhan dalam ,mengonsumsi obat, maka dibutuhkan teknik yang efektif dalam pendidikan kesehatan penderita.

Dari pendidikan kesehatan yang didapat oleh penderita menentukan ketaatan penderita minum obat sering diartikan sebagai usaha pasien untuk mengendalikan perilaku atau sikapnya apakah pasien mengikuti apa yang disampkain oleh petugas untuk dilaksanakan guna mencapai kesembuhan. Sikap dalam kehidupan seharihari adalah merupakan reaksi yang bersifat emosional terhadap stimulus sosial. Sikap belum merupakan suatu tindakan atau aktivitas, akan tetapi merupakan predisposisi tindakan/psikomotor atau perilaku (Taylor, 2017).

Sikap penderita kusta ingin berobat dengan patuh dibuktikan dengan kemampuannya dalam kemampuan penderita untuk melakukan perawatan pribadi, dengan diidentifikasi sebagai kemampuan mereka untuk memenuhi kebutuhan dasar manusia, mengontrol lingkungan hidup mereka, menggunakan alat pelindung diri, kulit dan perawatan luka, pencegahan kecacatan dan partisipasi dalam self care gorups (Sutanto, T., Dewi, EI., \& Rahmawati, I., 2017). Hasil penelitian pada penderita kusta di Kabupaten Gresik, bahwa ada pengaruh sikap penderita terhadap pengobatan dini dan pengobatan teratur, karena dengan pengobatan yang

Kepatuhan minum obat pada pasien merupakan suatu perilaku terbuka (overt behavior), pendidikan kepatuhan minum obat mengajak klien lebih berperilaku terbuka dan mampu menerima keadaannya sehingga bisa berkomitmen dengan keputusan yang dia buat (Notoadmodjo, 2007). Menurut Singh, Sinha, \& Jaswal (2013) adanya keyakinan, konstruksi pengetahuan atau pemahaman seseorang menentukan sebuah episode penyakit, penyebabnya, kronisitas dan modus dari onset gejala, patofisiologi penyakit, dan konsekueni dalam pengobatan merupakan faktor-faktor berperilaku sehat untuk mengatasi masalah kesehatannya. 
Selain faktor perilaku sehat, ada faktor lain yang harus diperhatikan untuk membahas mengenai kepatuhan seseorang dalam berobat, seperti yang diuraikan WHO (2003 dalam Gurumurthy, 2018) yaitu sosial ekonomi, provider pasien/sistem pelayanan kesehatan, terkait kondisi dengan rejimen pengobatan penyakit lain yang mneyertai, terkait obatnya, terkait kondisi pasiennya.

\section{KESIMPULAN}

Dimensi pengetahuan merupakan hal yang utama dalam menentukan perilaku sehat penderita kusta untuk melakukan kepatuhan dalam mengonsumsi MDT penyakit kusta. Secara keseluruahan koefisien determinan pengetahuan, sikap, dan perilaku terhadap kepatuhan penderita kusta mempunyai hubungan yang sangat kuat $(\mathrm{R}=0,809)$

Perlu diperhatikan dan digali lebih dalam faktor lain yang mempengaruhi perilaku sehat penderita kusta untuk melakukan kepatuhan dalam pengobatan MDT pada wilayah kerja Puskesmas lain dibawah Dinkes Kota Depok.

Peneliti mengharapkan tetap perlu dilakukan pengawas minum obat bagi penderita kusta, agar pengobatan penderita dalam mengonsumsi MDT maksimal dan tepat jangka waktunya, dan terhindar dari kecacatan. Puskesmas Limo perlu melakukan Training of trainer (TOT) bagi warga sekitar dan kader kesehatan untuk menjadi petugas penyuluh dan pengawas minum obat bagi penderita kusta.

\section{UCAPAN TERIMA KASIH}

Peneliti mengucapkan terima kasih kepada warga kelurahan Limo Kota epok yang telah berpartisipasi dalam proses penelitian, Dinkes Kota Depok, serta KesBangPol Kota Depok yang telah memberi izin untuk dilakukan penelitian ini. Ucapan terima kasih disampaikan kepada Universitas Pembangunan Nasional Veteran Jakarta yang telah mendanai kegiata penelitian ini

\section{REFRENSI}

Atre SR., Rangan, S. S. V. (2011). Perceptions, health seeking behaviour and access to diagnosis and treatment initiation among previously undetected leprosy cases in rural Maharashtra, India. Leprosey Review, 82, 222-234.

Benner, J. S., Glynn, R. J., Mogun, H., Neumann, P. J., Weinstein, M. C., \& Avorn, J. (2002). Long-term persistence in use of statin therapy in elderly patients. Journal of the American Medical Association, 288(4), 455-461. https://doi.org/10.1001/jama.288.4.4 55

Brown, M. T., Bussell, J., Dutta, S., Davis, K., Strong, S., \& Mathew, S. (2016). Medication Adherence : Truth. 351(4), 387-399.

https://doi.org/10.1016/j.amjms.2016 .01 .010

Bruner and Sudarth. (2014). Keperawatan Medikal Bedah (12th ed.). Jakarta: EGC.

Chin. J. (2006). Pemberantasan Penyakit Menular. Jakarta: Trans Info Media.

Cognizant. (2014). Medication Adherence in the Real World.

Cramer, J. A., Rosenheck, R., Kirk, G., Krol, W., \& Krystal, J. (2003). 
Medication compliance feedback and monitoring in a clinical trial: Predictors and outcomes. Value in Health, 6(5), 566-573.

https://doi.org/10.1046/j.1524-

4733.2003.65269.x

Depok Pos. Waspada Penularan Penyakit Kusta di Depok. , (2017).

Gurumurthy, R. (2018). Importance of medication adherence and factors affecting it. (June).

Hastono, S.P. (2018). Analisis Data PAda Bidang Kesehatan. Depok: Rajawali Pers.

Haynes, R. B., McDonald, H. P., \& Garg, A. X. (2002). Helping patients follow prescribed treatment: Clinical applications. Journal of the American Medical Association, 288(22), 2880-2883. https://doi.org/10.1001/jama.288.22. 2880

Irawati, Y., Dwi, Y., Puspitasari, A., \& Linuwih, S. (2018). Health care service for leprosy patients in Sitanala Tangerang ( $A$ proposed approach of comprehensive bealth care for Leprosy patient) bCebu Normal University, Philippines. 2(2).

Kaehler, N., Adhikar, B., Raut, S., \& Marahatta, S. B. (2015). Perceived Stigma towards Leprosy among Community Members Living Close to Nonsomboon Leprosy Colony in Thailand. 1-12. https://doi.org/10.1371/journal.pone. 0129086

Kemenkes RI. (2014). Buku Saku Pengendalian Kusta. Jakarta.

Kemenkes RI. (2015). Data Healt Indonesia 2015. https://doi.org/10.1111/evo.12990

Lehman. A. Assesing Medication Adherence: Options to Consider. , (2013).

Martin. (2002). Kamus Bahasa Indonesia Melenium. Surabaya: Karina.

Morisky, D. (2015). The influence of patients' knowledge on adherence to their chronic medications: a cross-sectional study in Jordan. (February). https://doi.org/10.1007/s11096-0150086-3

Nadhiroh, U., Dharmawan, R., \& Murti, B. (2016). Determinants of Disability in
Patients with Leprosy at Kelet Hospital, Central Java. 0273, 143-152.

Notoadmodjo. (2007). Pengantar Pendidikan Kesehatan Dan Perilaku. Jakarta: EGC.

Oliveira, A. R. De, Ha, K., Heukelbach, J., Andre, O., Henrique, C., Alencar, M. De, ... Ariza, L. (2011). Interruption and Defaulting of Multidrug Therapy against Leprosy : Population-Based Study in Brazil ' $s$ Savannab Region. 5(5), 4-9. https://doi.org/10.1371/journal.pntd. 0001031

Osteberg. (2015). Adherence to medication. Pediatriya, 55(2), 68-69. https://doi.org/10.1056/NEJMra050 100

Puskesmas Limo. Data Penderita Kusta di Puskesmas Kelurahan Limo. , (2018).

Rustam. (2014). Model Matematis Pengobatan Multy Drug Therapy Pada Penderita Kusta Tipe MB Yang Telah Release From Treatment di Provinsi Sulawesi Selatan (Tesis).

Selum \& Wahyuni. (2012). Risiko Kecacatan pada Ketidakteraturan Berobat Penderita Kusta di Kabupaten Pamekasan Provinsi Jawa Timur. The Indonesian Journal of Public Health, 8(3), 117-210.

Seshadri, D., Khaitan, B. K., Khanna, N., \& Sagar, R. (2014). The Tangled Web: A Study of Knowledge and Attitude towards Leprosy from a Tertiary Care Hospital in India. $27-41$.

Singh, S., Sinha, A. K., \& Jaswal, N. (2013). The Health-Seeking Behavior of Leprosy Patients. $4(1)$. https://doi.org/10.5195/hcs.2013.105

Siregar, T., \& Ratnawati, D. (2018). Pengalaman Keluarga Merawat Penderita Kusta dalam Menghadapi Stigma Masyarakat di Keluraban Limo Depok Jawa Barat. 1(2), 65-84.

Soedarto. (2002). Sinopsis Klinis, Penyebab Klinis, DiagnosisBanding , Diagnosis Laboraturium. Surabaya: Airlangga.

Sunyoto. (2011). Analisis Regresi dan Hipotesa. Yogyakarta: CAPS.

Sutanto, T., Dewi, EI., \& Rahmawati, I. (2017). The experiences of people affected by 
Care: Jurnal Ilmiah Ilmu Kesehatan Vol .7, No.3, 2019, hal 127-137

leprosy who participated in self-care groups in the community: A qualitative study in Indonesia. 543-553.

Taylor, S. (2017). Health Psychology (9, ed.).

WHO. (2014). Guidelines for the Diagnosis, Treatment and Prevention of Leprosy.
Wiyarni. (2013). Hubungan Kepatuhan Minum Obat Kousta Dan Dukungan Keluarga Dengan Kecacatan Pada Penderita Kusta di Kabupaten Kudus. Ejr.Stikesmubkudus.Ac.Id, 4(1). 